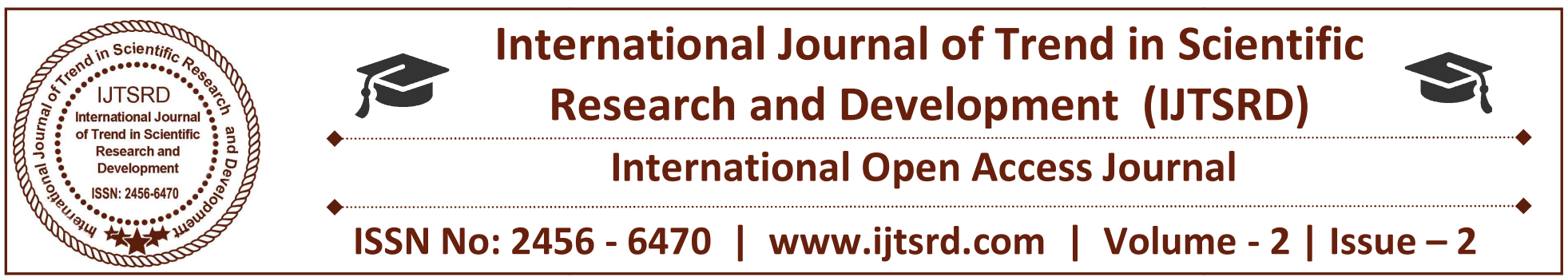

\title{
A Review on Rasamanjari: It's Contribution in Pharmaceutical Science
}

Dr. Versha Ratrey

PG Scholar, Department of RSBK, Govt. Ayurvedic College, Raipur, Chhattisgarh, India

\author{
Dr. Kavita
}

PG Scholar, Department of RSBK, Govt. Ayurvedic College, Raipur, Chhattisgarh, India
Dr. S. M. Parhate

Professor \& H.O.D., PG Department of RSBK, Govt. Ayurvedic College, Raipur, Chhattisgarh, India
Dr. K. S. Karbhal

Reader, PG Department of RSBK, Govt. Ayurvedic College, Raipur, Chhattisgarh, India

\section{Dr. M. K. Dash}

Lecturer, PG Department.of RSBK,

Govt. Ayurvedic College, Raipur, Chhattisgarh, India

\section{ABSTRACT}

Ayurveda is an ancient science. Rasashastra and bhaishajya kalpana is one of the important branch of Ayurveda. Rasamanjari is one of the compile text written by Acharya Shalinath. Hindi translation Siddhiprada written by Prof. Siddhi Nandan Mishra. Rasashastra is not included in Astang Ayurveda. Rasashastra deals with minerals and metals. Purificationof mineral metals and their formulation are clearly described in Rasamanjari. The pharmaceutical contribution of Rasamanjari is very beneficial for modern era.

Keywords: Rasashastra, Rasamanjari, Minerals, Metals etc.

\section{INTRODUCTION}

In ancient Ayurveda, the emphasis has been over the herbs and their therapeutic usages. Later on the animal product, metals and minerals started to find favor of the Ayurvedic practitioners. The minerals and metals are very effective the potent for immunization, rejuvenation and elimination of disease. The study of Dehavada and the use of metals were successful and it was found that the Mercury was very effective when compared to its other minerals and herbals counterparts. ${ }^{(1)}$ Rasamanjari is one of the compiled text written by ShriShalinath son of ShriVaidyanath. Its time period is 15 th century.Total 10 adhyaya are mentioned. Shri shalinath's time period his family and where the author belong these many questions are not answered yet. First published by Shri KrushnaDas, ShriGangavishnu, ShriKrushanlal. Hindi translation SIDDHIPRADA by Professor Siddhinandan Mishra. Rasamanjari is also mentioned in Rasendra-saar-sangrah.Rasamanjari starts with Ganaptibandana and Saraswatibandana. ${ }^{(2)}$

\section{MATERIALS \& METHODS}

Rasamanjari has 10 chapters, starting from description of parada and its importance in Alchemy. Each chapter of the book has its own importance. Its $7^{\text {th }}$ chapter also named as Rasayanadhikar and $10^{\text {th }}$ chapter is named as Arishtavigyaan because it'sexplained regarding Arista as a prognostic symptom. It is not only a text of Alchemy but also used as a medical treatise. All the chapters of Rasamanjari explained below. 


\section{$1^{\text {st }}$ chapter}

Total 37 shlokas. Description of Parad(Mercury), Importance of Parad,GunaDoshaShodhan of Parad.Shuddha-AshuddhaParadlakshan.Guru and shishyalakshan. Taptakhalwa. Hingulothaparadvidhi and guna. ${ }^{(3)}$

\section{$2^{\text {nd }}$ chapter}

This chapter explains about ParadMaran, Jaarna, Gold Jaarna, Murchhna. Process of making of 8 types Rasasindoor. Three types of making of Rasakarpoor. Explains about guna and lakshan of Murchhit and MaaritParad. Characteristics of BaddhaParad. And pathya-apathya during Paradsevenkaal. Rasakarpoor is a Kupipakwarasayan but ShriShalinath clearly mentioned DhamanYantra for making of Rasakarpoor. ${ }^{(4)}$

\section{$3^{\text {rd }}$ chapter}

This chapter contains 102 shlokas. Explains about 20 Uprasa. Samanyashodhan, maran of Uprasa. Also explainssamanyashodhan and maran of Ratnas.

Four types of GandhakRakta, Peet, Shweta, Krishna. RaktaGandhak is used for Dhatuwaad, PeetGandhak is used for Rasayankarma, Shweta is used for vraandi, KrishnaGandhak is rare and very useful.Rasarajterm used for Gandhak. GandhakDruti is also named as Gandhaktaila. Four types of Heerak. Eight types of Vaikrantaccording to varna. Satwapatan of vaikrant also explained. Four typesof Abhrak. Explained about Dhanyabhrakmaking, Abhrakdravan. Explained Bhoonagsatwapatan and Mudrikanirmaan. Three types of CovriesSardhnishka, nishka, paadonnishka. ${ }^{(5)}$

\section{$4^{\text {th }}$ chapter}

In this chapter 18 type of Kandavish. Lakshan, bheda, shodhan of poison\&antidote of vish. According to varnafour type of vishBrahmin, Kshatriya, Vaishya and Shudra. Vishsevan according to ritukaal (If shuddhavish taken in Sharad, Grishma, Basant and Varsharitu then it destroy kustha and lootavish effect.). Also explain about vishveganashaktantramantra. ${ }^{(6)}$

\section{$5^{\text {th }}$ chapter}

In this chapter general and specific shodhan of Dhatus. Maran and gunadharam of dhatu. Explain about suvarn, rajat, tamra, lauh, naag, vang, yashad, pittal, kansya and vart. 8 doshas of copper. Apathya during lauhsevankaal also explains mandoor. Nirutthikaran of lauha explained. ${ }^{(7)}$

\section{$6^{\text {th }}$ chapter}

This chapter contains 345 shlokas. Chapter starts with Dhanvantarivandana. Explains the importance of rasavaidya. In this chapter 81 anubhoot and pramanityoga. Importance of mantra for Rasusadhi. ${ }^{(8)}$

\section{$7^{\text {th }}$ chapter}

This chapter is also known as Rasayanadhikaar. Explains the process of kshetrikaran. Four rasayan yoga explains Gandhamruta rasayan, Hemsunder rasayan, Mrutasanjivani Gutika, Viryarodhini Gutika. ${ }^{(9)}$

\section{$8^{\text {th }}$ chapter}

This chapter contains 28 shlokas. Explains yoga for netrarog, Making process of anjana, matra and types. Dantaadivarti for savranshukra and avranshukra. Use of anjana after doshpaak mentioned. Pratyanjana, Keshranjantailaand palitroganashakyoga explained. Anjanavartimatra one harenu for tikshna, 1 $1 \frac{1}{2}$ for madhyamand 2 harenu for mriduanjana. ${ }^{(10)}$

\section{$9^{\text {th }}$ chapter}

total yoga explained 9 veeryasthambhanyoga, lingsthulikaranyoga, lingdhwastikaranyoga, 3 shandhatwakaranyoga, shandhatwanashanyoga, streedraavanyoga, vidweshikaran, lomshatan, bandhyakaranyoga, strivashikaranyoga, lomapatanyoga, garbhapradayoga, sukhprasavayoga. Also explained about Baaltantra, 16 yoginis. And bali, mantra, dishapuja for yoginishanti. ${ }^{(1)}$

\section{$10^{\text {th }}$ chapter}

This is last chapter of Rasamanjari. Also named Aristavigyaan. This chapter is about aristakaal. Aristalakshan of day, month, year. Symptoms of chhayapurush. This is only rasa text which explained regarding Arista as a prognostic symptom. ${ }^{(12)}$

\section{UNIQUE CONTRIBUTION}

- Rasamanjari has mentioned DhamanYantra for making Rasakarpoor.

- Rasaraj term used for Gandhak. 
International Journal of Trend in Scientific Research and Development (IJTSRD) ISSN: 2456-6470

- Explanation of Baltantra and 16 yoginis in $9^{\text {th }}$ chapter.

- This is only rasa text which explained about Arista as a prognostic system.

\section{DISCUSSION}

Overall Rasamanjari is a compile text which is very useful as a reference.In this bookcomplete description of Parad(Mercury) and its purification and formulations. Shodhan, Maran of Uprasa, Vish and Dhatus. Also explains Rasayanyoga, Arista as a prognostic system, Baltantra and yoginis.In $1^{\text {st }}$ chapter it's mainly described parad shodhan and guru shishya lakshan. Marana, jarana, murchhana, 8 types of rasasindoor, and 3 types of Rasakarpoor is described in $2^{\text {nd }}$ chapter. In $3^{\text {rd }}$ chapterclassification of rasa dravyas and in $4^{\text {th }}$ chapter it explained vish classification. In $5^{\text {th }}$ chapter Dhatu shodhan (purification of metals) and in $6^{\text {th }}$ chapter Dhanwantari vandana and 81 anubhoot and pramanit yoga is described. Kshetrikaran explained in $7^{\text {th }}$ chapter and different type of anjana andmedicine for netra roga are described in $8^{\text {th }}$ chapter. In $9^{\text {th }}$ chapter different types of yoga, 16 yoginis and Baaltantra is mentioned and in last chapter of Rasamanjari Arista lakshan is explained. In Rasamanjari wide range of rasa medicine preparation is explained. Its $7^{\text {th }}$ chapter also named as Rasayanadhikar and $10^{\text {th }}$ chapter is named as Arishtavigyaan because it's explained regarding Arista as a prognostic symptom.

\section{CONCLUSION}

This book is practically very useful. It is a compilation Alchemy along with many important creations and modifications of its own. This book can be taken as by the virtue of it's practical usefulness. The subject matter of the Rasamanjari of focused on performance and alternative methods of experimentation and medicine preparations. It has given unique contribution in its own experience. Rasamanjari is one of the finest text of its contemporary era.

\section{REFERENCES}

1. Dr. RAVINDRA ANGADI, A Text book of RASASHASTRA (IATRO-CHEMISTRY AND AYURVEDIC PHARMACEUTICS), CHAUKHAMBHA SURBHARTI PRAKASHAN VARANASI, Reprint Edition 2017
2. Prof. SIDDHI NANDAN MISHRA, RASA MANJARI (SHALINATH KRIT), CHAUKHAMBHA ORIENTALIA VARANASI, Reprint Edition 2015

3. Prof. SIDDHI NANDAN MISHRA, RASA MANJARI (SHALINATH CHAUKHAMBHA ORIENTALIA VARANASI, Reprint Edition 2015, pp 1-9

4. Prof. SIDDHI NANDAN MISHRA, RASA MANJARI (SHALINATH KRIT), CHAUKHAMBHA ORIENTALIA VARANASI, Reprint Edition 2015, pp 10-22

5. Prof. SIDDHI NANDAN MISHRA, RASA MANJARI (SHALINATH KRIT), CHAUKHAMBHA ORIENTALIA VARANASI, Reprint Edition 2015, pp 23-45

6. Prof. SIDDHI NANDAN MISHRA, RASA MANJARI (SHALINATH KRIT), CHAUKHAMBHA ORIENTALIA VARANASI, Reprint Edition 2015, pp 46-52

7. Prof. SIDDHI NANDAN MISHRA, RASA MANJARI (SHALINATH KRIT), CHAUKHAMBHA ORIENTALIA VARANASI, Reprint Edition 2015, pp 53-69

8. Prof. SIDDHI NANDAN MISHRA, RASA MANJARI (SHALINATH KRIT),

CHAUKHAMBHA ORIENTALIA VARANASI, Reprint Edition 2015, pp 70-132

9. " Prof. SIDDHI NANDAN MISHRA, RASA MANJARI (SHALINATH KRIT), CHAUKHAMBHA ORIENTALIA VARANASI, Reprint Edition 2015, pp 133-138

10. Prof. SIDDHI NANDAN MISHRA, RASA MANJARI (SHALINATH KRIT), CHAUKHAMBHA ORIENTALIA VARANASI, Reprint Edition 2015, pp 139-146

11. Prof. SIDDHI NANDAN MISHRA, RASA MANJARI (SHALINATH KRIT), CHAUKHAMBHA ORIENTALIA VARANASI, Reprint Edition 2015, pp 147-166

12. Prof. SIDDHI NANDAN MISHRA, RASA MANJARI (SHALINATH KRIT), CHAUKHAMBHA ORIENTALIA VARANASI, Reprint Edition 2015, pp 167-176 